\title{
Effects of Market Reforms and External Shocks on Indian Stock Indices: Evidence on Structural Breaks and Weak-Form Efficiency
}

\author{
Somnath Chattopadhyay ${ }^{1, *}$ and Suchismita Bose ${ }^{2, \#}$ \\ ${ }^{1}$ Department of Economics, Kandra Radha Kanta Kundu Mahavidyalaya (KRKKM), Burdwan, India \\ ${ }^{2}$ SURGE Research Support, Kolkata, India
}

\begin{abstract}
This study explores stock market efficiency in India after allowing for potential structural changes induced by reforms processes and/or external shocks. The endogenous determination of structural break dates, using mostly Clemente, Montãńes, \& Reyes (1998) (CMR) methodology, allows us to identify important events in this respect. External shocks such as occasional stock market scams, policy and political regime changes, oil price shocks and the effect of global market meltdowns have caused abrupt or one time changes in the series mean (additive outlier model), while the reforms processes stand out to be the single most important cause for the gradual shifts in the level of stock indices (innovation outlier model). This underlines the importance of institution building and the domestic policy stance in countering external shocks.
\end{abstract}

Keywords: Indian Stock Market, Efficient Market Hypothesis, Random Walk, Mean-Reversion, Structural Break, Unit Root Test.

\section{INTRODUCTION}

The structure of the Indian stock market has undergone a sea change since the early 1990s. Reforms in the stock market were accelerated by a stock market scam in 1992 that revealed serious weaknesses in the regulatory mechanism. The mélange of measures implemented include the establishment of a statutory regulator; promulgation of very high standards of rules and regulations for governing the different types of participants in the capital market and also for curbing activities like insider trading and hostile takeover bids; introduction of electronic trading to improve transparency in establishing prices; and dematerialization of shares to eliminate the need for physical movement and storage of paper securities. In addition, the opening up of financial markets led to heightened cross-border flow of capital with India emerging as an investment destination, resulting in the Indian stock market taking cues from and being impacted by global events. On the other hand, integration and capital flows have also made room for adoption of international best practices for the Indian market increasing its efficiency. In this backdrop, the present paper is an attempt to verify whether stock prices in India do follow a random walk or are mean-reverting in nature.

*Address of correspondence to this author at the Department of Economics, Kandra Radha Kanta Kundu Mahavidyalaya (KRKKM), Kandra, P.S. Ketugram, District: Burdwan, Pin: 713129; West Bengal, India; Tel: 03453 273372; Email: pikluchatterjee@gmail.com

"Both authors formerly affiliated to Indian Statistical Institute, Kolkata and ICRA Ltd. (A Moody's Investors Service Company), India.
A widely held belief in economics is that what goes up must eventually come down (DeBondt, 1991); for stock prices, this translates into the concept of (longrun) mean reversion which affirms that a drop in asset prices will in all probability be followed by an upward price movement and vice versa. The process of mean reversion is thus characterized by the existence of some sort of temporal dependence in the underlying data set which drives down a return process back to its mean. If market indices are mean-reverting, there is scope for predicting future stock prices based on the past values. On the other hand, in an (informationally) efficient market characterized by instantaneous price adjustment, successive price changes would be random. The stock prices would follow a random walka term used in finance to characterize a price series where all subsequent price changes represent random departures from previous prices (Malkiel, 2003). ${ }^{1}$ Deviations from the long run average return are thus unpredictable in the random walk model. The efficient market hypothesis (EMH) propounded by Fama (1970),

\footnotetext{
${ }^{1}$ The idea of a random walk model is built upon the notion of an unimpeded flow of information being absorbed into the prices instantaneously; this means that tomorrow's price will exactly correspond to tomorrow's news, the former being independent of price changes of today. But as news is, by definition unpredictable and random, the resulting price changes will be unpredictable and random. Formally, general random walks are stochastic processes satisfying the following equation:

$X_{t}=X_{0}+\sum_{k=1}^{t} Z_{k} ; t=1,2,3 \ldots \ldots \quad$ with independently and identically distributed increments $Z_{k}$. This means that at time t, the increment $Z_{t+1}$ is independent of the past values $X_{0}, X_{1}, \ldots \ldots, X_{t}$ so that the best prediction of $X_{t+1}$ is simply $X_{t}+E\left[Z_{t+1}\right]$.
}

E-ISSN: 1929-7092/17 
is the theoretical underpinning behind the random walk model. The EMH is a theory in financial economics that states that an asset's prices fully reflect all available information. A direct implication is that it is impossible to beat the market consistently on a risk-adjusted basis since market prices should only react to new information $^{2}$.

The validity of the random walk hypothesis has important implications for financial theories and investment strategies thereof. For investors, trading strategies need to be designed according to whether prices are characterized by random walks or by persistence in the short run, and mean reversion in the long run. An important point worth mentioning here is that market efficiency does not mean exact equivalence of the market price of a stock with its true value; it rather signifies that the errors in the market price, i.e. over- or under- valuation with reference to the true value should be unbiased and randomly deviated. Based on this argument, the existence of random deviation prevents investors from finding those over- or under-valued stocks ${ }^{3}$. In effect, what matters is the asymmetry in the dissemination of information that helps one to score over the market as against a situation where the market is informationally efficient with everyone having an equal access to information. Apart from the possibilities related to informed investors making abnormal profits, efficient market hypothesis has important implications for individual investors and policymakers in terms of allocative efficiency of investments. In case the stock market is inefficient, the pricing mechanism will not ensure efficient allocation of capital with a consequent negative impact on the economy. Evidence of inefficiency may, thus, prompt regulatory authorities to take appropriate steps and reforms so as to correct for it.

\footnotetext{
${ }^{2}$ There are three variants of the hypothesis: "weak", "semi-strong", and "strong" form. The weak form of the EMH claims that prices on traded assets already reflect all past publicly available information. The semi-strong form of the EMH claims both that prices reflect all publicly available information and that prices instantly change to reflect new public information. The strong form of the $\mathrm{EMH}$ additionally claims that prices instantly reflect even hidden insider information.

${ }^{3}$ However, dramatic asset price increases followed by a collapse, termed Bubbles, can occur if investors hold the asset because they believe that they can sell it at an even higher price to some other investor even though the asset's price exceeds its fundamental value. Some models analyze bubbles within the rational expectations paradigm, but may differ in their assumption whether all investors have symmetric information or are asymmetrically informed. Proponents of the efficient market hypothesis argue that bubbles cannot persist since well-informed sophisticated investors will undo the price impact of non-rational traders. However, the literature on limits to arbitrage challenges this view. It argues that bubbles can persist, and provides several channels that prevent rational arbitrageurs from fully correcting the mispricing, leading to a build up in asset price bubbles.
}

Reform processes are expected to amend the functioning of the stock market leading to higher degree of transparency and efficiency in the market so that the ultimate goals of investor protection and equitable capital allocation are met. While liberalisation, reforms and institution building have altered the nature of the Indian market, significant exogenous events which range from global and domestic political events, and global stock market crashes to financial crises, have had significant temporary or permanent impact on the market, possibly affecting the trend in stock prices. The present study complements the existing ones, described briefly in the next section, by re-investigating the random walk behaviour of several equity indices of two major stock exchanges in India, using a comprehensive updated data set. The period studied is characterised by numerous reforms initiatives, as well as, some dramatic changes associated with both global and domestic economic and political factors which may have affected stock index movements. This study makes an attempt to gauge whether any structural changes have developed as an outcome and if so the nature of the events leading to such changes. Most importantly, since structural changes are unlikely to take place abruptly, one should adopt the concept of a gradual structural break. This can intuitively be related to some underlying process requiring an incubation and maturation time rather than being dependent on some arbitrary states. The present study addresses this issue and thus adds to the existing literature by estimating, for the first time, both abrupt and gradual (endogenously determined) structural breaks in the Indian stock prices, and their effect on stock market efficiency in India.

The rest of the paper is organized as follows. Section 2 presents some of the relevant literature. Section 3 describes the conventional methodology as well as those incorporating the structural breaks for testing the presence of unit roots. Section 4 details the data, while some crucial events pertinent to the current analysis are also described. Section 5 presents the results, while, Section 6 concludes.

\section{LITERATURE REVIEW}

Empirical studies would usually employ conventional unit root tests to examine the issue of market efficiency or the random walk hypothesis. The presence of a unit root suggests that shocks to the price series are permanent causing an irreversible departure from the equilibrium price path, implying that future price movements cannot be predicted based on 
information about past changes. The Dickey and Fuller (1979) methodology has traditionally been used to test for the presence of a unit root. But later studies by Perron (1989) and Zivot and Andrews (1992) demonstrated that the Dickey-Fuller test fails to take account of a structural break in the series. In the presence of a structural break, the power of a unit root test decreases when the stationary alternative is true (Perron 1989). As Perron argues, most macroeconomic time-series are not structurally characterized by unit roots, though they might appear to be because of the presence of some large and infrequent shocks; the series might eventually, revert to the (long-run) deterministic trend path. If structural changes are present in the data generating process but not incorporated in the unit root test specification, results may be biased towards flawed non-rejection of the nonstationary hypothesis (Leybourne, Mills, \& Newbold, 1998). An appropriate way would be to test for the presence of structural breaks while employing tests for efficiency or testing the EMH. Perron's (1989) uses a modified Dickey-Fuller (DF) unit root tests that include dummy variables to account for one known, or exogenous structural break. Since then, to avoid the personal judgment involved in determining the break, several studies have developed different methodologies for endogenously determining the break date(s). Some of these include Banerjee, Lumisdaine and Stock (1992), Zivot and Andrews (1992), Perron and Vogelsang (1992), Perron (1997) and Lumsdaine and Papell (1998), and Clemente, Montañés and Reyes (1998). These studies have shown that bias in the usual unit root tests can be reduced by endogenously determining the time of structural breaks.

Nelson and Plosser (1982) pointed out that random shocks to macroeconomic data may have, not only transitory, but also permanent effects on the underlying series causing structural breaks in the data. These breaks can emerge as a sudden abrupt change due to some external shock or evolve through a continuous and dynamic process. This study incorporates the above phenomena while testing for market efficiency. It is pertinent to mention here some of the factors which impede the flow of information particularly in the thinly traded emerging markets ${ }^{4}$. First, illiquidity restricts the market's capacity to accommodate orders (Chordia, Roll, \& Subrahmanyam, 2005). Second, a strong

\footnotetext{
${ }^{4}$ See Lagoarde-Segot \& Lucey (2008).
}

competition cannot obtain in the presence of dominant players who can make stock prices deviate from their intrinsic value (Mobarek \& Keasey, 2000). Third, fundamental information is truncated owing to a lack of market transparency, as reflected by corporate information scarcity, inferior auditing experience, lax disclosure requirements, and overall weak regulations (Blavy, 2002). Fourth, low efficiency can be attributed to a number of structural and institutional specificities, such as the fragmentation of capital markets, or the presence of political and economic uncertainties (ElErian \& Kumar, 1995). Finally, due to the lack of a culture of equity, the reaction of market participants to information tends to be slow, thus diminishing efficiency (Aloui, 2005).

A general consensus is that stock prices in developed markets are found to exhibit a random walk, whereas there are no definite conclusions regarding stock prices in emerging markets. ${ }^{5}$ Empirical studies testing market efficiency for the Indian market, while endogenously determining the structural break dates, are rather few; they include studies by Sasidharan (2009), Hiremath and Kamaiah (2010) and Mishra, Mishra and Smyth (2014). The study of stock price behaviour in India began with early work of Rao and Mukherjee (1971) providing evidence on market efficiency based on a single stock price (Indian Aluminium). Subsequent studies using various methods, indices and sets of stock prices, over different time horizons, have again produced rather conflicting results. Early studies have generated significant evidence in favour of weak form efficiency of the Indian stock markets. More recent evidence is provided by Aggarwal (2012), while Jethwani \& Achuthan (2013) and Suri (2015) also corroborate the findings of market efficiency. On the contrary, opposite results on testing the weak form efficiency were obtained by Ahmad et al. (2006), Gupta and Basu (2007), and Mishra (2012), among others, who found stock prices to be predictable. A pre-determined division of the sample period into sub-periods has often produced mixed evidence on market efficiency in different sub-periods according to a few studies like Gupta and Yang (2011). This indicates the need for testing the EMH with the presence of structural breaks in the series under consideration; exploration of Indian market data in this vein is limited. However, few studies do confirm the existence of structural breaks and find

${ }^{5}$ Lim and Brooks (2011) provide a comprehensive review the relevant literature on emerging market efficiency. 
evidence of divergent results when structural breaks are endogenously determined. Sasidharan (2009) locates structural breaks in the index using BaiPerron's method for endogenous multiple structural changes. Using non-parametric methods the efficiency of the market across the periods corresponding to the structural breaks are tested. Though the null hypothesis of random walk for the entire return series for the period 1991 to 2008 is rejected, it is found that the markets have become weak-form efficient since the second half of 2003, corresponding to the period of the third structural break identified. Hiremath and Kamaiah (2010) found significant structural breaks in the returns series of all selected indices. They, however, provide evidence of mean-reverting tendency in the Indian stock returns refuting market efficiency. Mishra et al. (2014) find that unit root tests that allow for two structural breaks do not reject the null of a unit root. ${ }^{6}$

\section{METHODOLOGY}

Conventionally the random-walk behaviour of a time series is tested by looking for the presence of unit root in the same. A time series characterized by a unit root is non-stationary in nature in the sense that mean and variance of the underlying series change over time. As the conventional test for testing the presence of unit root in a time series (stock prices), Dicky Fuller (DF) Test involves fitting the model: $y_{t}=\alpha+\rho y_{t-1}+\delta t+u_{t}$ by Ordinary Least Squares (OLS), setting $\alpha=0$ or $\delta=0$. However, such a regression is likely to be affected by serial correlation. To control for that the augmented Dickey-Fuller test (ADF) instead fits the model of the form: $\Delta y_{t}=\alpha+\beta y_{t-1}+\delta t+\zeta_{1} \Delta y_{t-1}+\zeta_{2} \Delta y_{t-2}+\cdots+\zeta_{k} \Delta y_{t-k}+u_{t}$; where $\mathrm{k}$ is the number of lags specified in the system. In the ADF set-up, testing $\beta=0$ is equivalent to testing $\rho=1$, which is the same as saying that the series $\left(y_{t}\right)$ follows a unit-root process, or implicitly, that the series is not mean-reverting in nature.

Tests attempting to differentiate between a unit root and a (trend) stationary process tend to support the unit root model if the true process is subject to some structural changes. However, the process could be (trend) stationary in periods in between structural breaks - tests probing into the possible presence of a structural change will reject the null hypothesis of no structural change in case the process has a unit root component. Further, failing to consider the effect of a structural break might result in the flawed acceptance

\footnotetext{
${ }^{6}$ However, using a unit root test that simultaneously accounts for heteroskedasticity and structural breaks, they find that the stock indices are mean reverting.
}

of the null of unit root producing a type-II statistical error under the conventional DF and ADF unit-root tests.

In view of the possibilities mentioned above, a significant amount of literature has emerged in exploration of the presence of unit root under possible structural break(s). The Phillips and Perron (PP) unit root test, for example, extends the ADF specification using dummy variables to allow for a single exogenous structural break in the series. Here the null of a unit root is tested against the alternative specification of stationarity around a break in the level (Perron, 1989). Some theoretical and empirical literature however considers the PP method to be inappropriate as the break date is specified ex ante (Banerjee, Lumsdaine, \& Stock, 1992; Perron \& Vogelsang, 1992, Zivot \& Andrews, 1992).

As on this, i.e., the selection of break date, the Zivot \& Andrews (1992) unit root test (ZA) assumes that the exact time of the break point is unknown and regards every point as a potential break by running a regression for every possible break date sequentially. The ZA test while utilizing the full sample uses a different dummy variable for each possible break date. The optimal break date is chosen to be the one where the t-statistics of the model is at a minimum, i.e., the evidence is least favorable in support of the null of unit root. This test allows for a single structural break in the intercept and the trend of the series, as determined by a 'grid search' over possible breakpoints. Subsequently, the procedure conducts a DF style unit root test on the series inclusive of the estimated optimal breaks. Lumsdaine \& Papell (1997) argued that unit root test accounting for two structural breaks (if significant) is more powerful than those considering a single break. The (Bai \& Perron, 1998) method tests for multiple structural changes.

An extension of the ZA statistic, the (Perron \& Vogelsang, 1992) and the (Perron, 1997) statistics allow for two different forms of structural breaks allowing for changes in both level and trend in the series, viz., the Additive Outlier (AO) and Innovational Outlier (IO) models. The AO model is designed so as to allow for sudden changes in mean, while the 10 model takes account of changes that are gradual. In other words, AO models will be more appropriate when there is a one-time shock which significantly affects the mean. 10 models will be appropriate if the one-time shock persists dynamically throughout the series. 
The Clemente, Montãnes, \& Reyes (1998) (CMR) methodology allows for two breaks/events within the observed history of a time series. This test has the desirable property of being applicable for identifying an unknown break date occurring under both the hypotheses of stationary and non-stationary states. Secondly, if the series does exhibit a break, CMR test utilizes this information to enhance the power of the test itself. The tests devise "level-shift" models, "changing-growth" models, and "mixed" models, allowing for shifts in both the level and slope. Furthermore, this test verifies the existence either of an additive outlier (AO) or of an innovational outlier (IO).

The present paper implements the CMR methodology (both the $I O$ and the $A O$ models) in order to identify events causing transitory shocks and those having a more gradual and permanent impact on Indian stock indices. Consider a series $z_{t}$ (without any disturbances) and a disturbance term $f(t)$ so that $y_{t}=z_{t}+f(t)$. The functional form of $f(t)$ depends on the nature and type of the outlier. For an additive outlier, ${ }^{7} f(t)=\delta I_{t}\left[t=T_{A O}\right]$ and so the AO model is: $y_{t}=z_{t}+\delta I_{t}\left[t=T_{A O}\right]$; where $I_{t}[$.] is an indicator dummy variable observed for $t=1,2, \ldots, T$. It takes a value of 1 when $t=T_{A O}$ and a value of zero otherwise. The time series $z_{t}$ is the uncontaminated but unobserved time series, while $y_{t}$ is the observed variable. The size of the outlier is denoted by $\delta$. Assuming an autoregressive structure AR (1) with drift, an additive outlier can be specified as: $y_{t}=\mu+\delta I_{t}\left[t=T_{A O}\right]+z_{t} ; z_{t}=\phi z_{t-1}+\varepsilon_{t}$. The innovation outlier $(\mathrm{IO})$ is a type of observation where the outlier has its origin in the underlying noise process. With an $A R(1)$ structure with drift, for example, the functional form of $f(t)$ is given by: $f(t)=\frac{1}{1-\rho L} \delta I_{t}\left[t=T_{I O}\right]$ which leads to the specification for the innovational outlier model as: $y_{t}=\mu+z_{t}+\frac{1}{1-\rho L} \delta I_{t}\left[t=T_{I O}\right] ; \quad z_{t}=\rho z_{t-1}+\varepsilon_{t}$; In this case, the behaviour of the series $y_{t}$ depends on the autoregressive structure of $z_{t}$ which, for simplicity, has been assumed here to be an AR(1) model. The innovational outlier affects the $T_{I O}{ }^{\text {th }}$ observation by $\delta$

\footnotetext{
${ }^{7}$ An additive outlier is a type of observation in which the genuine data point is contaminated with some positive or negative value. The contamination is either due to errors in recording the observation or due to misinterpretation of sudden news-a common occurrence in stock markets where prices shoot up or slump in an instant reaction to some news which, though, may not appear as important subsequently. In other words, the aberrance of the data point is due to some factor, which is extraneous to the intrinsic economic environment constituting the DGP.
}

and affects the subsequent observations by $\rho^{t-T_{I O}} \delta$. Thus its impact on the subsequent observations decay at the rate $\rho$. The double-break additive outlier AO model implemented by Baum, Barkoulas, \& Caglayan (1999) is a two-step procedure built upon the CMR methodology, the first stage involving the estimation of the following equation:

$y_{t}=\mu+\delta_{1} D U_{1 t}+\delta_{2} D U_{2 t}+\tilde{y}_{t} ;$

Here $D U_{m t}=1$ for $\mathrm{t}>T_{b m}$ and 0 otherwise, for $\mathrm{m}=$ 1, 2. $T_{b 1}$ and $T_{b 2}$ are the breakpoints resulting from the shifts in the mean, to be located by a process of grid search. The residuals from this regression, i.e., $\tilde{y}_{t}$ are the dependent variable in the next equation (2) to be estimated. The residuals are regressed on their lagged values, a number of lagged differences, and a set of dummy variables such that the distribution of the test statistic is tractable:

$$
\begin{aligned}
& \tilde{y}_{t}=\sum_{i=1}^{k} w_{1 i} D T_{b 1, t-i}+\sum_{i=1}^{k} w_{2 i} D T_{b 2, t-i}+\alpha \tilde{y}_{t-i} \\
& +\sum_{i=1}^{k} \theta_{i} \Delta \tilde{y}_{t-i}+e_{t}
\end{aligned}
$$

Here $D T_{b m, t}$ is a pulse variable taking the value (= 1) for $\mathrm{t}=T_{b m}+1$ and 0 otherwise, for $\mathrm{m}=1$, 2. It should be noted that because the mean of $\tilde{y}_{t}$ is zero, no intercept term is considered here. Equation (2) is estimated over feasible pairs of $T_{b 1}$ and $T_{b 2}$, searching for the minimal t-ratio for the hypothesis $\alpha=1$. The value of this minimal t-ratio is compared with critical values provided by (Perron \& Vogelsang, 1992), as they do not follow the standard DF distribution. The null hypothesis here is that the series has a unit root with structural breaks against the alternative hypothesis that they are stationary with structural breaks.

The IO variant of the above model expresses the shocks to the series (the effects of $\delta_{1}$ and $\delta_{2}$ below) as having the same ARMA representation as other shocks to the model, leading to the formulation as given below:

$$
\begin{aligned}
& y_{t}=\mu+\delta_{1} D U_{1 t}+\delta_{2} D U_{2 t}+\phi_{1} D T_{b 1, t}+\phi_{2} D T_{b 2, t} \\
& +\alpha y_{t-i}+\sum_{i=1}^{k} \theta_{i} \Delta y_{t-i}+e_{t} ;
\end{aligned}
$$

An estimate of $\alpha$ significantly less than unity will provide evidence against the $I(1)$ null hypothesis.

In each of these models (AO/IO), the breakpoints $T_{b 1}, T_{b 2}$ and the appropriate lag order $\mathrm{k}$ are unknown. While the breakpoints can be found by a twodimensional grid search procedure, $\mathrm{k}$ is determined by a set of sequential F-tests. 


\section{THE DATA AND SOME RELEVANT EVENTS}

The data-set for this study consists of monthly index values of several indices from two premier stock exchanges of India, viz., the Bombay Stock Exchange (BSE) and the National Stock Exchange of India (NSE) for the period January 1995 to July 2015. The Indian market's bellwether index the S\&P BSE Sensex (S\&P BSE Sensitive Index), also-called the BSE 30 or simply the Sensex, is a free-float market capitalization weighted stock market index of 30 most actively traded liquid stocks listed on the BSE. ${ }^{8}$ The 30 component companies which are some of the largest and most well-established and financially sound are representative of the key industrial sectors of the Indian economy. Launched on January 1, 1986, the Sensex is regarded as the pulse of the domestic stock markets in India. It is also traded internationally on the EUREX as well as leading exchanges of Brazil, Russia, China and South Africa. We also consider the broader indices like the S\&P BSE 100 and the S\&P BSE 200. The S\&P $B S E 500$ is a broad based 500 -stocks index traded on the BSE, which represents nearly 93 per cent of the total market capitalization on BSE and covers 20 major industries of the economy. The NSE's flagship index, the Nifty 50 index is a well diversified 50 -stocks index covering 23 sectors of the Indian economy. It serves as the benchmark for Indian capital markets and offers investment managers an exposure to its constituents in a single portfolio. This index like the Sensex is also used for a variety of purposes such as benchmarking fund portfolios, index based derivatives and index funds. The Nifty Next 50 (previously Nifty Junior) represents the next tier of liquid securities after the Nifty and together comprises the Nifty 100 index, the 100 most liquid stocks traded on the NSE. The Nifty 500 index, a broad based benchmark index of the Indian capital market is a 500-stocks index representing about 96 per cent of the free float market capitalization of the companies listed on the NSE. We also include two sectoral indices, the NSE Bank Nifty index, the barometer for banking sector stocks, and the $S \& P$ BSE PSU index designed to measure the performance of public sector undertakings (PSUs), to see whether sectoral indices behave any differently compared with broader indices.

Before going into the details of the Indian stock market data and implementing meaningful statistical

\footnotetext{
${ }^{8}$ More than 5500 companies are listed on BSE making it world's No. 1 exchange in terms of listed members. The companies listed on BSE command a total market capitalization of USD 1.64 trillion as of September 2015.
}

testing procedures thereof, one may take stock of some of the crucial events pertinent to the current analysis. We first present the timeline of some of the institutional changes systematically implemented to improve the functioning of the capital markets in India. Meanwhile, the infrastructure of the primary capital market has also been strengthened over the years with improved disclosure standards, prudential norms, and simplification in the procedures of security issues. The market depth and width has also increased with a number of investment bankers, investment and consulting agencies and registrars to issues joining the market. While the institutional participation has expanded, retail participation has been made safer and easier. Further, the integration with global markets and the adoption of international best practices has continued with foreign investment norms still being simplified, ceilings raised, and the scope widened $^{9}$ (Jadhav, 2006; Bose and Coondoo, 2004; and Mukherjee and Bose, 2008). We also list some external shocks to the stock market encompassing domestic and international events like political instability, monetary policy regime changes, oil price shocks, stock market scams, global market meltdowns and financial crises. Some major reforms initiatives and intra- and inter-national events, with severe impacts on the Indian stock market are listed in Table 1 below.

\section{THE RESULTS}

The Indian stock market has shown phenomenal growth over the course of the last two decades, though with significant volatility. The time series plot for all the indices is presented in Figure 1.

Some of the stylised facts of Indian stock prices during the period under study are presented in the Appendix. A comparison of the 10 -yearly returns ${ }^{10}$ between the periods (1995-2005) and (2005-2015) reveals that that on the whole, the market is characterised by a positive returns for all the indices. In fact returns have increased manifold in each decade, with the second period (2005-2015) showing far higher returns post the completion of several reforms initiatives. Again average monthly returns are positive

\footnotetext{
${ }^{9}$ Individual Flls were allowed to invest 5 per cent and all Flls were allowed to invest up to 24 per cent of a company's issued capital since 1992. This ceiling has been revised upwards since 2001 till 2015 and several different restricted sectors have been brought under the ambit of foreign investment. In December 2003 , foreign investor's dual regulatory approval process of SEBI and RBI was changed to a single approval process by SEBI.

${ }^{10}$ Return is calculated as $R T=\frac{P_{t}-P_{t-1}}{P_{t-1}}, P_{t}$ being the index value at time $\mathrm{t}$.
} 


\section{Table 1: Time-Line of Reforms and Major Events}

\section{Reforms}

In India the Securities Contracts (Regulation) Act, 1956 (SCRA) was in place to provide for direct and indirect control of virtually all aspects of securities trading and its regulation. Major reforms initiatives were undertaken when in 1992 a massive securities scam surfaced involving a diversion of funds from the banking system, in particular the inter-bank market in government securities, to brokers for financing their operations in the stock market. To improve market efficiency, enhance transparency, prevent unfair trade practices and bring the Indian market up to international standards, a package of reforms consisting of measures to liberalize, regulate, digitize and develop the securities market were implemented since then. An autonomous agency, the Securities and Exchange Board of India (SEBI) was set up on April 12, 1992 in accordance with the provisions of the Securities and Exchange Board of India Act, 1992. SEBI was empowered adequately and assigned the responsibility to protect the interests of investors in securities, promote the development of the securities market, and regulate the securities market. In the interest of investors, SEBI issued Disclosure and Investor Protection (DIP) guidelines. A major initiative of liberalization was the repeal of the Capital Issues (Control) Act, 1947 in May 1992; with this, government's control over issue of capital and pricing of the issues ceased and the market-determined allocation of resources was allowed.

To counter the conflict of interest noticed in an owner driven environment of the BSE which had been in existence since 1875, the NSE, which was set up by leading institutions in 1992, commenced equity trading in 1994. A major developmental initiative with NSE was a nation-wide on-line fully-automated screen based trading system (SBTS), which matches orders anonymously on a strict price/time priority and hence reducing trading time, cost and risk of error as well as fraud, resulting in improved operational efficiency. It also allowed faster incorporation of price sensitive information into prevailing prices, thus increasing the informational efficiency of markets."

In 1995 the BSE On-Line Trading (BOLT) system replaced the open outcry system of order matching. Clearing corporations emerged to assume counter party risk. Trade and settlement guarantee funds were set up to guarantee settlement of trades irrespective of default by brokers. These funds provide full novation and work as central counter party.

The Depositories Act, 1996 was passed to provide for the establishment of depositories in securities with the objective of ensuring free and secure transferability of securities with speed and accuracy by dematerializing the securities in the depository mode. The National Securities Clearing Corporation Ltd. (NSCCL), a wholly owned subsidiary of NSE, was incorporated in August 1995 and commenced operations in 1996. National Securities Depository Limited (NSDL) is an Indian central securities depository was established in 1996 and CSDL was set up in 1999 to enhance the process of dematerialization of securities.

To assist market participants to manage risks better through hedging, speculation and arbitrage, SCRA was amended in 1995 to lift the ban on options in securities. The SCRA was amended further in December 1999 to expand the definition of securities to include derivatives so that the whole regulatory framework governing trading of securities could apply to trading of derivatives also.

Derivatives trading took off in June 2000 on the two major exchanges with the introduction of index futures and by 2001 index options and individual stock futures trading also commenced.

SEBI took up further reforms as a follow-up to a stock market scam and crash in March 2001. A major development was the move to rolling settlement of securities; after some experimentation, all scrips moved to rolling settlement from December $2001 .^{\dagger}$ In order to reduce large open positions, the trading cycle was reduced over a period of time to a week initially. Rolling settlement on a $T+5$ basis was introduced in phases; $T+5$ gave way to $T+3$ from April 2002 and T+2 from April 2003, guaranteeing liquidity and cleaner prices.

In 2003, SEBI made the Unique Identification Number (UID) compulsory for all market participants to maintain up-to-date information on all market participants.

In 2004 the SCRA was revised to recognise delisting of companies to allow for compulsory delisting, in case of prolonged losses, nontrading, violation of norms etc., and for optional delisting as well, adding a much needed exit route for companies from the stock market.

Since late 1990s SEBI has also continuously engaged with the International Organization of Securities Commissions (IOSCO), the international body that brings together the world's securities regulators and is recognized as the global standard setter for the securities sector.

\section{Major Events}

The Asian currency crisis broke out in July 1997 with Thailand abandoning its currency peg and consequent devaluation of the Baht, which led to meltdown in currencies across Asia and triggered bankruptcies and stock market crashes during 1997 till 1999.

The Pokhran-II nuclear tests set off a worldwide storm of reactions leading to the imposition of a raft of economic sanctions by the US on May 13,1998, the immediate fallout of which on the bourses was a panic sell-off.

The Kargil war between India and Pakistan from May to July 1999 became an event of much international concern because of the nuclear capabilities of both countries.

In January, 2000, the bursting of the dot.com bubble, and accompanying bankruptcies or at least major decline in values and earnings reassessments by several major highgrowth internet based companies.

\section{Effect on the Stock Market}

SENSEX dropped from a level of 4256 by the end of June 1997 to 3876 by the end of August 1997

SENSEX registered the highest intra-day decline of 4.01 percent on May 13 , 1998

SENSEX shed 100 points or so every time there was rumour of escalating tension on the border. In the aftermath of war Indian stock markets rose by more than 30 percent.

From a high of 6,150 in February-2000, SENSEX dropped to 3,943 in May2000. In the same period, the BSE IT index fell by 71 per cent. Other sectors such as- auto, capital goods, healthcare and metal suffered losses of 20-40 percent. Led by a fall in the NASDAQ, Indian indices too kept declining with high volatility till early 2003 . 
The unearthing of another major case of market manipulation through bullish activities of an influential broker in March 2001.

Formation of Coalition Government with Outside Support from the Left Parties in May 2004.

The U.S. subprime crisis broke out in October 2007, with the nation's top investment banks expecting to take USD100 billion or more in write-downs because of subprime losses with the bursting of the housing bubble; this affected financial markets worldwide. The collapse of Lehman Brothers in September 2008 initiated the largest bankruptcy proceedings in the U.S. history and triggered massive financial and economic turmoil across the globe, the effect of which still hasn't dissipated.

In the May 2009 victory of Congress-Led Government Led by Dr. Manmohan Singh was perceived as a public endorsement for the continuation of economic reforms and liberalization policies that had been ushered in by Manmohan Singh in 1991.

In May, 2014 there was a change in the political regime when the Bharatiya Janata Party (BJP) led by Narendra Modi came to power with an absolute majority riding high on expectations around furthering economic reforms that had built up during the run-up to the elections.
The sudden 176 point crash of SENSEX on March 2, 2001.

SENSEX dropped by 565 points on May 17, its third biggest fall ever, to close at 4,505. Automatic circuit breakers in both NSE and BSE were activated. The Sensex rose almost continuously since May 2004 from a level of about 4,700, to the historical high of 8,500 on September 20, 2005 and moved higher to reach the 10,000 mark in early February 2006. The index kept on increasing thereafter to reach 11,350 by the end of the financial year in March 2006 and crossed 12,600 on May 10, 2006, registering an increase of more than 25 per cent in just two months. After a brief gap the Sensex continued its upward journey and breached 15,000 in July 2007 and touched 20,000 by October 2007.

The Sensex, which had closed December 2007 above the 20,000 mark continued to move lower since then. SENSEX fell by $5.4 \%$ on September 15 , 2008. After reaching its crisis induced ebb in February 2009, the Sensex recovered quite rapidly from an average closing value of below 9,000 to above 17,000 by September 2009 and above 20,000 in another year's time.

The SENSEX surged 14.70 percent on the results day. The Sensex remained range bound within 18,000 and 22,000 in the next few years.

SENSEX soared by 1,470 points to hit a record high of $25,375.63$ in early trade. The bullish environment continued for almost a year, with the Sensex briefly breaching the 30,000 mark in March 2015 . The exuberance came to pass though as the economy's recovery remained slow and the country's external environment clouded visibly.

\#It enabled market participants to see the full market on real-time, making the market transparent. It allowed a large number of participants, irrespective of their geographical locations, to trade with one another simultaneously, improving the depth and liquidity of the market.

The gap between the trade date and the settlement date is less under rolling settlement adding liquidity and reducing risk of default. Rolling settlement, which segregates cash and futures markets and thereby removes excessive speculation, helps in better price discovery.

for all the indices over the sample period. However, the average values do not decisively suggest any short term profitability, as we observe large standard deviations in all index returns suggestive of large volatility in returns.

The empirical analysis begins with testing for the unit roots in the logarithm of the monthly index values using the conventional ADF tests. All the three variants of the ADF test are used, i.e., the ADF test including both constant and trend, ADF test including constant but no trend, and the one excluding both constant and trend. It is observed that for all the indices and for all three variants of the ADF tests, the estimated ADF $t$ statistics (in absolute terms) are less than the DickeyFuller critical values at $5 \%$ level of significance for all the indices. This leads us to the acceptance of the null that the index values do contain unit roots.

As regards the ZA test, in all of its three variants, viz., the break in intercept, break in trend and break in both trend and intercept, the absolute values of the estimated $t$-statistics come out to be less than the critical values at all levels of significance. Again the null of a unit root is accepted for all the indices under consideration. As for the break dates in the series, the tests identify statistically significant break dates for each series. The break date for level shifts in both the Sensex and Nifty are the same and occur in May 2005, identifying a time when the indices, consequent on a series of reforms, almost doubled in the span of a year and moved up continuously there from, touching new record highs till the outbreak of the U.S. subprime crisis. The break date for a shift in trend in the Sensex and Nifty occur around the major scam in early 2001, after which a slew of reforms were implemented for mitigating investor risk. The single break date in both level and trend for all the indices is identified as immediately after the stock markets moving to $\mathrm{T}+2$ rolling settlements in April $2003^{11}$.

\footnotetext{
${ }^{11}$ The Tables showing the results of ADF and ZA tests have been omitted here due to lack of space. These may however be provided to interested readers on request.
} 


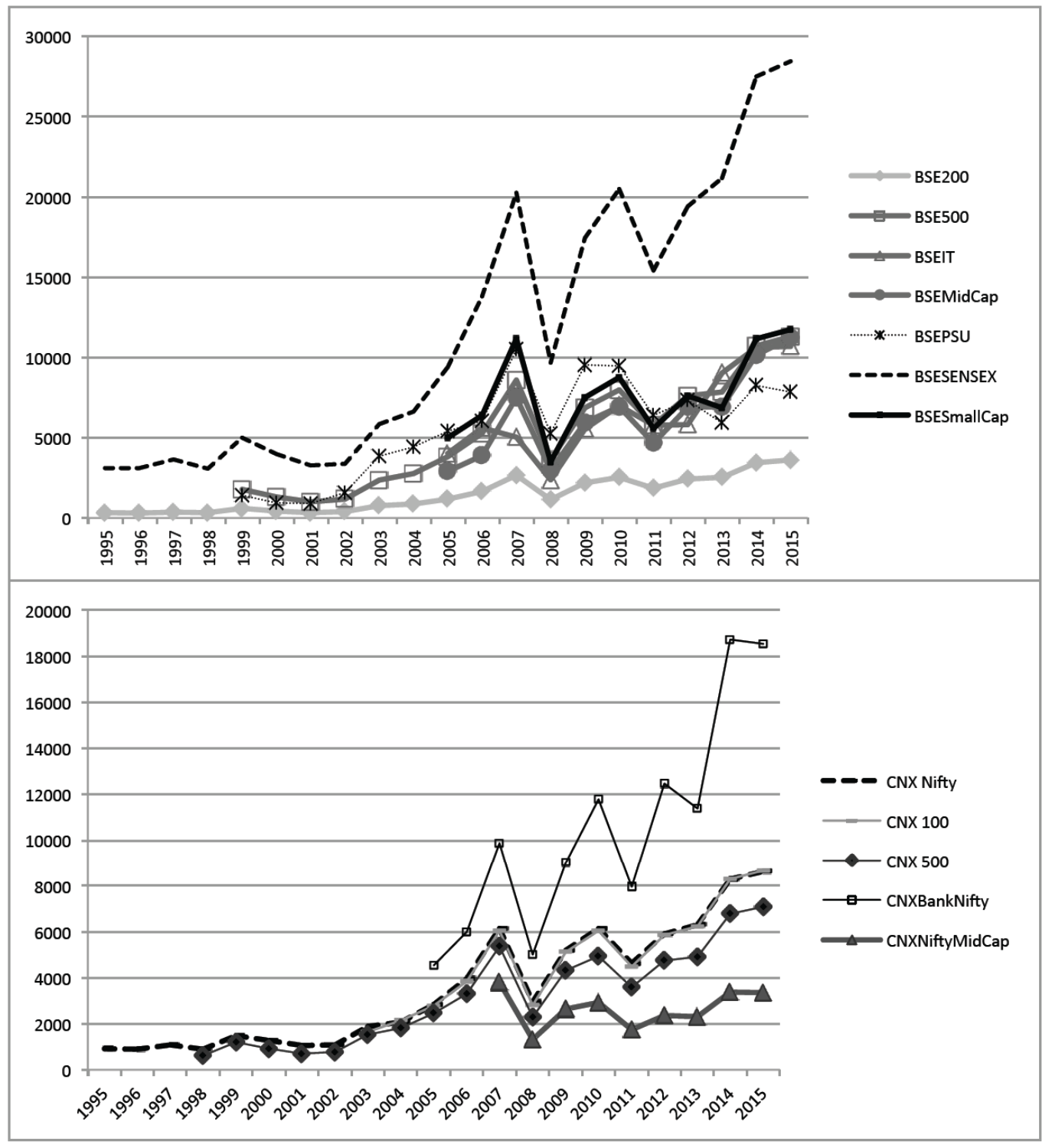

Figure 1: BSE and NSE Index Values over the Years.

The second table in the Appendix gives the result of the CMR single mean shift $A O$ model testing for the presence of a single structural break in the underlying series. Comparing the estimated $t$-statistics associated with $\delta_{1}$ and $\alpha(=\rho-1)$ with the tabulated values, it can be inferred that each series is characterized by the existence of a single and statistically significant structural break and each is non-stationary in nature. The next Appendix table presents analogous results for the IO variant of the above model. The final two tables in the Appendix give the results of CMR double mean shift models respectively for the $A O$ and $I O$ variants. As the estimated $t$-statistics associated with $\delta_{1}, \delta_{2}$ and $\alpha(=\rho-1)$ suggest, two structural breaks are present in each series which is characterized by the presence of a single unit root. As the results suggest, the indices have experienced both abrupt and gradual structural breaks in the mean.
Figure 2 displays the break-dates corresponding to the AO- and IO- type CMR unit root tests. One of the optimal break dates, estimated from the AO model (single and double break point) is in May 2006, which corresponds to the second sharpest decline in the history of the indices till then, driven by U.S. policy rate hikes and a global meltdown in commodity prices. This was exacerbated by large scale foreign investment withdrawals consequent on soft Asian markets and intensified by some announcements regarding the tax regime that adversely affected foreign investors investing in India. The AO type CMR tests with double break dates show that the first break date estimated as January 2004 (for the Sensex, and March 2004 for Nifty), corresponds to a period of sharp recovery in the Indian market to historic highs post the 2000 dot.com crisis. Various one off factors, like encouraging 
SINGLE MEAN SHIFT, AO MODEL

May 2006

BSE Sensex, BSE 100, BSE 200, BSE 500, CNX Nifty, CNX 500

DOUBLE MEAN SHIFTS, AO MODEL

January 2004 \& May 2006

BSE Sensex, BSE 100, BSE 200, BSE 500, CNX 500

March 2004 \& May 2006

CNX Nifty
SINGLE MEAN SHIFT, IO MODEL

March 2003

BSE Sensex, BSE 100, BSE 200, BSE 500, CNX Nifty, CNX 500

DOUBLE MEAN SHIFTS, 10 MODEL

March 2003 \& January 2009

BSE Sensex, BSE 100, BSE 200, BSE 500, CNX Nifty, CNX 500

Figure 2: Optimal Break Dates from the Clemente-Montañés-Reyes Unit-root Tests.

quarterly results by major corporates, strong institutional support, especially by foreign investors, positive trends in international markets, contributed to the buoyant market sentiments which supported the rally $^{12}$.

One of the optimal break dates, in March 2003, implied by the 10 models (both single and double break point), in turn corresponds to the period around the completion of a reforms process of migration to the $T+2$, from $T+3$ rolling settlement for all stocks in the Indian market. This measure ensured far greater liquidity and cleaner prices. The period also marks the beginning of a turnaround following almost three years of lull as an after effect of the bursting of the dot.com bubble and associated fall in Indian markets, driven by technology stocks, in line with their global counterparts. In the IO type CMR tests with double mean shifts, the second break date, January 2009, corresponds to the initial period of recovery, in India, from the 2007 financial crisis. It is well known that India was one of the first countries to bounce back from the sub-prime crisis boosted by monetary policy and mostly strong fiscal stimulus ${ }^{13}$.

Thus the $\mathrm{AO}$ and $\mathrm{IO}$ break point tests clearly show that while external shocks, either domestic or global, and contagion effects can cause onetime structural shifts in stock prices, the process of institution building has a gradual, though lasting beneficial effect on the markets and can effectively counter the ill-effects of any detrimental external shock.

In all of the models considered here, appropriate incorporation of the structural break suggests

\footnotetext{
${ }^{12}$ Some domestic sector-specific factors together with strong macroeconomic fundamentals along with the appreciation in the Rupee were also in play.

${ }^{13}$ The fiscal stimulus measures included both tax cuts and increase in expenditure. Again, unlike in many countries, the entire fiscal stimulus in India was aimed at addressing the deficiency in aggregate demand rather than extending support to the financial sector. The Reserve Bank, like most central banks, took a number of conventional and unconventional measures to augment domestic and foreign exchange liquidity, and sharply reduced the policy rates.
}

characterization of random walk behaviour as against the tendency of mean-reversion at any level of significance in the Indian stock prices, implying (weakform) efficiency for Indian stock prices.

\section{CONCLUDING OBSERVATIONS}

This paper seeks evidence on efficiency of the Indian stock market and tests the random walk hypothesis for the some major Indian stock market indices. The EMH provides a theoretical basis for empirically testing for the degree of success in achieving market efficiency, whereby finding evidence in favour of market efficiency is equivalent to testing some form of the random walk hypothesis for the relevant stock prices. The existence of conflicting evidence on the random walk hypothesis in the presence of structural breaks with Indian data, as described in Section 2, points to the need for further exploration.

The significant contribution of the present study is that it employs unit root tests with endogenously determined multiple structural breaks to account for both abrupt and gradual shifts in the observed time series of the stock prices in India. An external shock can impact either as an additive outlier in which a single point in the series is affected causing a sudden change in its mean or as an innovative outlier where an innovation to the process affects both an observation and the subsequent series causing a gradual shift in the mean. Moreover, multiple events/breaks might be present within a given time-span. The present approach is an all-around investigation seeking to address all these econometric issues, while testing the (weak-form) EMH. As a corollary the break dates have also been endogenously determined and their statistical significance in turn validates the acceptability of the present methodology. The output from all the four tests applied-the ADF and modified versions of the ADF (viz., PP, ZA \& CMR) tests-gives strong evidence in favour of the null of unit root, which in 
effect, confirms the notion of market efficiency. One can conclude in line with the efficient market hypothesis that Indian stock market is weak-form efficient whereby current stock prices tend to fully reflect all information contained in the historical prices. Our results thus invalidate the applicability of technical analysis for finding undervalued stocks or of forecasting future returns based on past information in the Indian context consistently over a prolonged period of time. Most importantly, an informationally efficient market enhances the allocative efficiency of investments consistent with the basic aim of investors or policymakers, as the market price is an unbiased estimate of the true value of the investment ${ }^{14}$.

Further, the identification of the breaks in the data from both the $A O$ and $I O$ models help to understand the nature of events that have impacted the Indian stock markets over time. It is seen from the AO models that external shocks in the form of occasional stock market scams, U.S. monetary policy changes, political regime change, oil price shocks and the effect of global

\footnotetext{
${ }^{14}$ One however, would like to test with weekly or daily data over and above monthly data, as we have done in this study, to gauge the degree of sophistication of the market in terms of information dissemination and its absorption into stock prices.
}

\section{Appendix}

\section{Long-Term and Short-Term Return on Stocks (1995-2015)}

\begin{tabular}{|c|c|c|c|c|}
\hline \multirow{3}{*}{ NSE Stocks } & CNX Nifty & 212.21 & 203.53 & 847.67 \\
\hline & CNX 500 & & 187.80 & \\
\hline & CNX Bank Nifty & & 308.85 & \\
\hline \multirow{5}{*}{ BSE Stocks } & BSE 100 & 246.20 & 203.84 & 951.88 \\
\hline & BSE 200 & 278.17 & 204.75 & 1052.47 \\
\hline & BSE 500 & & 197.50 & 530.39 \\
\hline & BSE SENSEX & 202.14 & 202.87 & 815.07 \\
\hline & BSE Small-Cap & & 134.98 & \\
\hline
\end{tabular}

market meltdowns can cause an abrupt or one time change in the series mean, as also corroborated by other studies like Hiremath and Kamiah (2010). On the other hand, the 10 model identifies structural break dates that correspond to the implementation of major stock market and/or economic reforms. Thus the reforms processes stand out to be the single most important cause for a gradual (upward) shift in the level of stock indices in India, whether it be regulatory reforms like the shift to a $\mathrm{T}+2$ rolling settlement as witnessed in April 2003, or the continuity of economic reforms despite political regime change as evidenced in May 2005, or the provision of fiscal and monetary stimulus undertaken during the 2007-08 financial crisis that had led to sustained recovery from January 2009. This together with the evidence on market efficiency underlines the importance of institution building and the domestic policy stance in the movement of stock markets in emerging economies like India, given the fact that they are most likely to be occasionally affected by contagion effects from global markets. What stands out is that, even though asset price bubbles may form and burst the responses of the domestic policy makers, be it regulatory, monetary or fiscal, are of crucial importance in thwarting or magnifying further the crisis in the financial and real sectors. 


\begin{tabular}{|c|c|c|c|c|c|c|c|}
\hline \multicolumn{2}{|c|}{ Short-term Return on Stocks (\%) } & \multirow{2}{*}{$\begin{array}{c}\begin{array}{c}\text { No of } \\
\text { Observations }\end{array} \\
246\end{array}$} & \multirow{2}{*}{$\begin{array}{r}\text { Mean } \\
1.11\end{array}$} & \multirow{2}{*}{$\begin{array}{c}\text { Skewness } \\
-0.15\end{array}$} & \multirow{2}{*}{$\begin{array}{c}\text { Min } \\
-26.41\end{array}$} & \multirow{2}{*}{$\begin{array}{c}\text { Max } \\
28.07\end{array}$} & \multirow{2}{*}{$\begin{array}{c}\begin{array}{c}\text { Standard } \\
\text { Deviation }\end{array} \\
7.15\end{array}$} \\
\hline \multirow[b]{2}{*}{ NSE Stocks } & CNX Nifty & & & & & & \\
\hline & CNX 500 & 198 & 1.56 & -0.25 & -27.23 & 34.43 & 8.03 \\
\hline \multirow{5}{*}{ BSE Stocks } & BSE 100 & 246 & 1.18 & -0.12 & -25.97 & 31.29 & 7.77 \\
\hline & BSE 200 & 246 & 1.20 & -0.17 & -26.36 & 32.36 & 7.74 \\
\hline & BSE 500 & 197 & 1.55 & -0.29 & -27.11 & 33.33 & 7.98 \\
\hline & BSESENSEX & 246 & 1.10 & -0.06 & -23.89 & 28.25 & 7.19 \\
\hline & BSE Small-Cap & 118 & 1.20 & 0.33 & -33.54 & 47.80 & 9.37 \\
\hline
\end{tabular}

\section{Clemente-Montañés-Reyes Unit-Root Test with Single Mean Shift, AO Model}

\begin{tabular}{|c|c|c|c|c|}
\hline \multicolumn{5}{|c|}{ H0: BSE 100 has unit root with structural break } \\
\hline AR(1) & $\delta_{1}$ & $\alpha=\rho-1$ & Constant & 7.06599 \\
\hline Coefficients & 1.50591 & -0.07643 & & Decision \\
\hline \multirow{2}{*}{ t-statistics } & 34.665 & -3.265 & & \\
& $(0.000)$ & $(-3.560)$ & \\
\hline Optimal Break Point & May 2006 & & \\
\hline
\end{tabular}

\begin{tabular}{|c|c|c|c|c|}
\hline \multicolumn{5}{|c|}{ H0: BSE 200 has unit root with structural break } \\
\hline t-statistics & $\begin{array}{l}33.479 \\
(0.000)\end{array}$ & $\begin{array}{l}-3.183 \\
(-3.560)\end{array}$ & & Accept $\mathrm{HO}$ \\
\hline \multicolumn{5}{|c|}{ HO: BSE 500 has unit root with structural break } \\
\hline$A R(1)$ & $\delta_{1}$ & $\alpha=\rho-1$ & Constant & Decision \\
\hline Coefficients & 1.39278 & -0.07669 & & Accept $\mathrm{HO}$ \\
\hline
\end{tabular}




\begin{tabular}{|c|c|c|c|c|}
\hline \multicolumn{5}{|c|}{ HO: BSE SENSEX has unit root with structural break } \\
\hline$A R(1)$ & $\delta_{1}$ & $\alpha=\rho-1$ & Constant & Decision \\
\hline Coefficients & 1.43256 & -0.08218 & 8.33654 & \\
\hline t-statistics & $\begin{array}{l}36.911 \\
(0.000)\end{array}$ & $\begin{array}{c}-3.354 \\
(-3.560)\end{array}$ & & Accept $\mathrm{HO}$ \\
\hline Optimal Break Point & May 2006 & & & \\
\hline \multicolumn{5}{|c|}{ HO: CNX Nifty has unit root with structural break } \\
\hline$A R(1)$ & $\delta_{1}$ & $\alpha=\rho-1$ & Constant & Decision \\
\hline Coefficients & 1.41686 & -0.06642 & 7.14542 & \multirow[b]{2}{*}{ Accept HC } \\
\hline t-statistics & $\begin{array}{l}35.980 \\
(0.000)\end{array}$ & $\begin{array}{c}-2.789 \\
(-3.560)\end{array}$ & & \\
\hline Optimal Break Point & May 2006 & & & \\
\hline \multicolumn{5}{|c|}{ HO: CNX 500 has unit root with structural break } \\
\hline AR(1) & $\delta_{1}$ & $\alpha=\rho-1$ & Constant & Decision \\
\hline Coefficients & 1.35560 & -0.07965 & 6.96651 & \multirow[b]{2}{*}{ Accept HO } \\
\hline t-statistics & $\begin{array}{l}26.718 \\
(0.000)\end{array}$ & $\begin{array}{c}-3.148 \\
(-3.560)\end{array}$ & & \\
\hline Optimal Break Point & May 2006 & & & \\
\hline
\end{tabular}

\section{Clemente-Montañés-Reyes Unit-Root Test with Single Mean Shift, 10 Model}






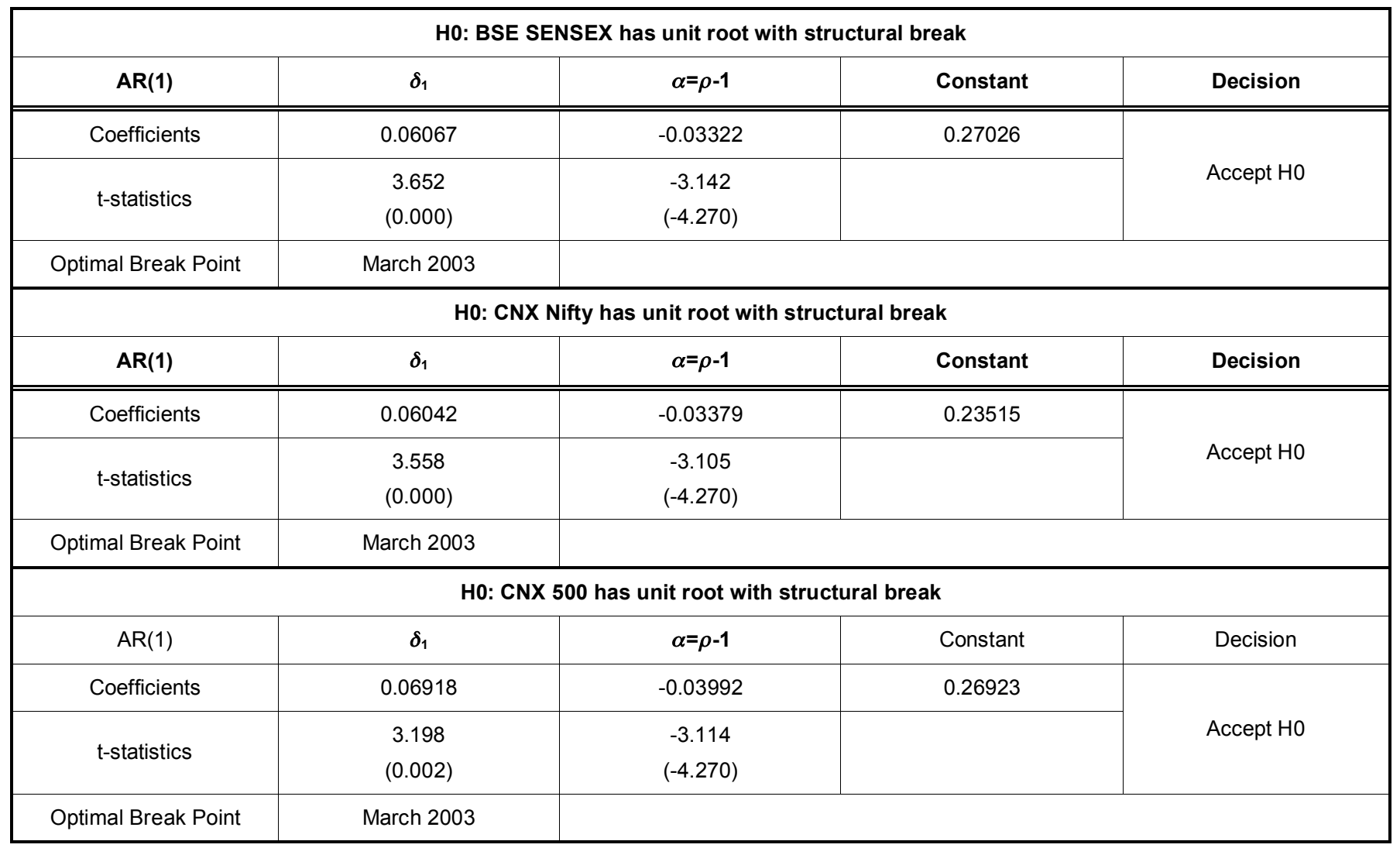

\section{Clemente-Montañés-Reyes Unit-Root Test with Double Mean Shifts, AO Model}

\begin{tabular}{|c|c|c|c|c|c|}
\hline$A R(1)$ & \multicolumn{5}{|c|}{ H0: BSE 100 has unit root with structural break } \\
\hline Coefficients & 0.77817 & 0.88679 & -0.10941 & 6.90695 & \multirow[b]{2}{*}{ Accept $\mathrm{HC}$} \\
\hline t-statistics & $\begin{array}{l}14.953 \\
(0.000)\end{array}$ & $\begin{array}{l}17.056 \\
(0.000)\end{array}$ & $\begin{array}{c}-3.815 \\
(-5.490)\end{array}$ & & \\
\hline \multirow[t]{2}{*}{ Optimal Break Points } & January 2004 & May 2006 & & & \\
\hline & \multicolumn{5}{|c|}{ H0: BSE 200 has unit root with structural break } \\
\hline$A R(1)$ & $\delta_{1}$ & $\delta_{2}$ & $\alpha=\rho-1$ & Constant & Decision \\
\hline Coefficients & 0.84854 & 0.85069 & -0.11167 & 5.96973 & \multirow[b]{2}{*}{ Accept $\mathrm{HO}$} \\
\hline t-statistics & $\begin{array}{l}16.149 \\
(0.000)\end{array}$ & $\begin{array}{l}16.205 \\
(0.000)\end{array}$ & $\begin{array}{c}-3.884 \\
(-5.490)\end{array}$ & & \\
\hline Coefficients & 0.80163 & 0.84622 & -0.11514 & 7.16471 & \multirow[b]{2}{*}{ Accept $\mathrm{HO}$} \\
\hline t-statistics & $\begin{array}{l}13.243 \\
(0.000)\end{array}$ & $\begin{array}{l}15.115 \\
(0.000)\end{array}$ & $\begin{array}{c}-3.597 \\
(-5.490)\end{array}$ & & \\
\hline Optimal Break Points & January 2004 & May 2006 & & & \\
\hline
\end{tabular}




\begin{tabular}{|c|c|c|c|c|c|}
\hline \multirow[b]{2}{*}{$A R(1)$} & \multicolumn{5}{|c|}{ H0: BSE SENSEX has unit root with structural break } \\
\hline & $\delta_{1}$ & $\delta_{2}$ & $\alpha=\rho-1$ & Constant & Decision \\
\hline Coefficients & 0.67099 & 0.88891 & -0.10502 & 8.20920 & \multirow[b]{2}{*}{ Accept $\mathrm{HO}$} \\
\hline t-statistics & $\begin{array}{l}13.326 \\
(0.000)\end{array}$ & $\begin{array}{l}17.638 \\
(0.000)\end{array}$ & $\begin{array}{c}-3.750 \\
(-5.490)\end{array}$ & & \\
\hline \multirow[t]{2}{*}{ Optimal Break Points } & January 2004 & May 2006 & & & \\
\hline & \multicolumn{5}{|c|}{ H0: CNX Nifty has unit root with structural break } \\
\hline$A R(1)$ & $\delta_{1}$ & $\delta_{2}$ & $\alpha=\rho-1$ & Constant & Decision \\
\hline Coefficients & 0.68677 & 0.86043 & -0.10088 & 7.01509 & \multirow[b]{2}{*}{ Accept $\mathrm{HO}$} \\
\hline t-statistics & $\begin{array}{l}13.530 \\
(0.000)\end{array}$ & $\begin{array}{l}16.936 \\
(0.000)\end{array}$ & $\begin{array}{c}-3.646 \\
(-5.490)\end{array}$ & & \\
\hline Coefficients & 0.79897 & 0.79211 & -0.12336 & 0.48331 & \multirow[b]{2}{*}{ Accept $\mathrm{HO}$} \\
\hline t-statistics & $\begin{array}{l}13.920 \\
(0.000) \\
\end{array}$ & $\begin{array}{c}14.60 \\
(0.000) \\
\end{array}$ & $\begin{array}{c}-3.781 \\
(-5.490) \\
\end{array}$ & & \\
\hline Optimal Break Points & January 2004 & May 2006 & & & \\
\hline
\end{tabular}

\section{Clemente-Montañés-Reyes Unit-Root Test with Double Mean Shifts, IO Model}

\begin{tabular}{|c|c|c|c|c|c|}
\hline$A R(1)$ & \multicolumn{5}{|c|}{ H0: BSE 100 has unit root with structural break } \\
\hline Coefficients & 0.08736 & 0.04968 & -0.06736 & 0.46223 & \multirow[b]{2}{*}{ Accept $\mathrm{HO}$} \\
\hline t-statistics & $\begin{array}{c}4.485 \\
(0.000)\end{array}$ & $\begin{array}{c}2.928 \\
(0.004)\end{array}$ & $\begin{array}{c}-4.434 \\
(-5.490)\end{array}$ & & \\
\hline Optimal Break Points & March 2003 & January 2009 & & & \\
\hline$A R(1)$ & $\delta_{1}$ & $\delta_{2}$ & $\alpha=\rho-1$ & Constant & Decision \\
\hline Coefficients & 0.09552 & 0.05244 & -0.07169 & 0.42456 & \multirow[b]{2}{*}{ Accept HO } \\
\hline t-statistics & $\begin{array}{c}4.631 \\
(0.000)\end{array}$ & $\begin{array}{c}3.103 \\
(0.002)\end{array}$ & $\begin{array}{c}-4.596 \\
(-5.490)\end{array}$ & & \\
\hline Optimal Break Points & \multicolumn{5}{|c|}{ H0: BSE 500 has unit root with structural break } \\
\hline$A R(1)$ & $\delta_{1}$ & $\delta_{2}$ & $\alpha=\rho-1$ & Constant & Decision \\
\hline Coefficients & 0.08999 & 0.05063 & -0.07045 & 0.50257 & \multirow[b]{2}{*}{ Accept HO } \\
\hline t-statistics & $\begin{array}{c}4.033 \\
(0.000)\end{array}$ & $\begin{array}{c}2.911 \\
(0.004) \\
\end{array}$ & $\begin{array}{c}-4.362 \\
(-5.490)\end{array}$ & & \\
\hline \multirow[t]{2}{*}{ Optimal Break Points } & March 2003 & January 2009 & & & \\
\hline & \multicolumn{5}{|c|}{ H0: BSE SENSEX has unit root with structural break } \\
\hline$A R(1)$ & $\delta_{1}$ & $\delta_{2}$ & $\alpha=\rho-1$ & Constant & Decision \\
\hline Coefficients & 0.07561 & 0.04583 & -0.06258 & 0.51062 & \multirow[b]{2}{*}{ Accept $\mathrm{HO}$} \\
\hline t-statistics & $\begin{array}{c}4.437 \\
(0.000)\end{array}$ & $\begin{array}{c}2.894 \\
(0.004)\end{array}$ & $\begin{array}{c}-4.352 \\
(-5.490)\end{array}$ & & \\
\hline
\end{tabular}




\begin{tabular}{|c|c|c|c|c|c|}
\hline $\operatorname{AR}(1)$ & \multicolumn{5}{|c|}{ H0: CNX Nifty has unit root with structural break } \\
\hline Coefficients & 0.07733 & 0.04733 & -0.06527 & & \multirow[b]{2}{*}{ Accept $\mathrm{HO}$} \\
\hline t-statistics & $\begin{array}{c}4.394 \\
(0.000)\end{array}$ & $\begin{array}{c}2.946 \\
(0.004)\end{array}$ & $\begin{array}{c}-4.347 \\
(-5.490)\end{array}$ & & \\
\hline Optimal Break Points & March 2003 & January 2009 & & & \\
\hline $\operatorname{AR}(1)$ & $\delta_{1}$ & $\delta_{2}$ & $\alpha=\rho-1$ & Constant & Decision \\
\hline Coefficients & 0.08873 & 0.04929 & -0.07193 & 0.48331 & \multirow[b]{2}{*}{ Accept HO } \\
\hline t-statistics & $\begin{array}{c}3.988 \\
(0.000)^{*}\end{array}$ & $\begin{array}{c}2.829 \\
(0.005)^{\star}\end{array}$ & $\begin{array}{c}-4.288 \\
(-5.490)^{\star *}\end{array}$ & & \\
\hline
\end{tabular}

*Figures in parentheses denote P-values; **figures in parentheses denote $5 \%$ critical values.

\section{REFERENCES}

Aggarwal, M. 2012. "Efficiency of Indian Capital Market: A Study of Weak Form of EMH on Nifty." Academicia 2(6): 16-28.

Ahmed, K. M., S. Ashraf and S. Ahmed. 2006. "Testing Weak Form Efficiency of Indian Stock Markets." Economic and Political Weekly 41(1): 49-56.

Aloui, C. 2005. "Long-range Dependence in Daily Volatility on Tunisian Stock Market." Economic Research Forum Working Paper 40.

Bai, J, and P Perron. 1998. "Estimating and Testing Linear Models with Multiple Structural Changes." Econometrica 66 (1): 4778.

https://doi.org/10.2307/2998540

Banerjee, A, R L Lumsdaine, and J H Stock. 1992. "Recursive and Sequential Tests of the Unit-Root and Trend-Break Hypotheses: Theory and International Evidence." Journal of Business \& Economic Statistics 10: 271-287. https://doi.org/10.1080/07350015.1992.10509905

Baum, C F, J T Barkoulas, and M Caglayan. 1999. "Long Memory or Structural Breaks: Can either Explain Nonstationary Exchange Rates under the Current Float." Journal of International Financial Markets, Institutions, and Money 9 (4):359-376.

https://doi.org/10.1016/S1042-4431(99)00018-9

Baum, Christopher F. 2005. "Stata: The Language of Choice for Time-Series Analysis?" Stata Journal 5 (1):46-63.

Blavy, R. 2002. "Changing Volatility in Emerging Markets: a Case Study of Two Middle Eastern Stock Exchanges." Revue Entente Cordiale Autumn 2(1):1-35.

Bose, S. and D. Coondoo. 2004. "The Impact of FII Regulations in India: A Time-Series Intervention Analysis of Equity Flows." Money \& Finance July-December. https://papers.ssrn.com/ sol3/papers.cfm?abstract_id $=755324$

Chordia, T, R Roll, and A Subrahmanyam. 2005. "Evidence on the Speed of Convergence to Market Efficiency." Journal of Financial Economics 76 (2): 271-292. https://doi.org/10.1016/j.jfineco.2004.06.004

Clemente, J, A Monta n'es, and M Reyes. 1998. "Testing for a Unit Root in Variables with a Double Change in the Mean." Economics Letters 59 (2):175-182. https://doi.org/10.1016/S0165-1765(98)00052-4

DeBondt, W.F.M. 1991. "What Do Economists Know about the Stock Market." Journal of Portfolio Management 17: 84-91.

Dickey, D A, and W Fuller. 1979. "Distribution of the Estimators for Autoregressive Time Series with a Unit Root." Journal of the American Statistical Association 74 (366):427-431. https://doi.org/10.2307/2286348
El-Erian, M A, and M S Kumar. 1995. "Emerging Equity Markets in Middle Eastern Countries." International Monetary Fund Staff Paper 42 (2): 313-343. https://doi.org/10.2307/3867575

Fama, E F. 1991. "Efficient Capital Markets: II." Journal of Finance 46 (5): 1575-1617. https://doi.org/10.1111/j.1540-6261.1991.tb04636.x

Fama, Eugene F. 1970. "Efficient Capital Markets: A Review of Theory and Empirical Work." Journal of Finance 25 (2 ): 383417.

https://doi.org/10.2307/2325486

Gupta, R. and P.K. Basu. 2007. "Weak Form Efficiency of Indian Stock Markets." International Business and Economics Research Journal 6:57-64.

Gupta, R. and J. Yang. 2011."Testing Weak form Efficiency in the Indian Capital Market." International Research Journal of Finance and Economics 75:108-119.

Hiremath, G S, and B Kamiah. 2010."Do Stock Returns in India Exhibit a Mean-Reverting Tendency? Evidence from Multiple Structural Breaks Test." Banking and Finance Letters 2(4): $371: 390$.

Jadhav. N. 2006. "Development of Securities Markets: The Indian Experience." in China and India: Learning from Each Other: Reforms and Policies for Sustained Growth. International Monetary Fund.

Jethwani, Kinjal, and Sarla Achuthan. 2013. "Stock Market Efficiency and Crisis:Evidence from India." Asia-Pacific Finance and Accounting Review 1(2):35-43.

Lagoarde-Segot, Thomas, and Brain M Lucey. 2008. "Efficiency in Emerging Markets-Evidence from the MENA Region." Journal of International Financial Mrkets, Institutions \& Money 18 (1):94-105. https://doi.org/10.1016/j.intfin.2006.06.003

Leybourne, S, T Mills, and P Newbold. 1998. "Spurious Rejections by Dickey-Fuller Tests in the Presence of a Break under the Null." Journal of Econometrics 87(1):191-203. https://doi.org/10.1016/S0304-4076(98)00014-1

Lumsdaine, R, and D Papell.1997. "Multiple Trend Breaks and the Unit Root Hypothesis." Review of Economics and Statistics 79 (2):212-218. https://doi.org/10.1162/003465397556791

Malkiel, B G. 2003. "The Efficient Market Hypothesis and ts Critics." Journal of Economic Perspectives 17(1): 59-82. https://doi.org/10.1257/089533003321164958

Mishra, Ankita, Vinod Mishra, and Russel Smyth. 2014. "The Random-Walk Hypothesis on the Indian Stock Market." Monash University Department of Economics Discussion Paper 07/14. 
Mishra, P.K. 2012. "Efficiency of South Asian Capital Markets An Empirical Analysis." Pakistan Journal of Commerce and Social Sciences 6 (1): 27-34.

Mobarek, A, and K Keasey.2000. "Weak form Efficiency of an Emerging Market: Evidence from Dhaka Stock Market of Bangladesh." Paper Presented at the ENBS Conference held on Oslo.

Mukherjee, P. and S. Bose. 2008. "Does the Stock Market in India Move with Asia? A Multivariate Cointegration-Vector Autoregression Approach." Emerging Markets Finance \& Trade 44(5): 5-22. https://doi.org/10.2753/REE1540-496X440501

Nelson, C. R. and C. I. Plosser.1982. "Trends and Random Walks in Macroeconomic Time Series: Some Evidence and Implications." Journal of Monetary Economics 10(2): 139162. https://doi.org/10.1016/0304-3932(82)90012-5

Perron, P. 1989. "The Great Crash, the Oil Price Shock, and the Unit Root Hypothesis." Econometrica 57(6): 1361-1401. https://doi.org/10.2307/1913712

Perron, P. 2006. "Dealing with Structural Breaks." Pp. 278-352 in Palgrave Handbook of Econometrics. Vol. 1, edited by K. Patterson and T. C. Mills : Palgrave Macmillan

Perron, P. 1997. "Further Evidence on Breaking Trend Functions in Macroeconomic Variables." Journal of Economics 80 (2): 355-385. https://doi.org/10.1016/S0304-4076(97)00049-3
Perron, P. (1990)."Testing for a Unit Root in a Time Series with a Changing Mean." Journal of Business \& Economic Statistics $8(2): 153-162$. https://doi.org/10.1080/07350015.1990.10509786

Perron, P. (1989). "The Great Crash, the Oil Price Shock, and the Unit Root Hypothesis." Econometrica 57 (6):1361-1401. https://doi.org/10.2307/1913712

Perron, $\mathrm{P}$, and $\mathrm{T} \mathrm{J}$ Vogelsang. 1992. "Testing for a Unit Root in a Time Series with a Changing Mean: Corrections and Extensions." Journal of Business \& Economic Statistics 10(4):467-470. https://doi.org/10.1080/07350015.1992.10509923

Rao, Krishna N, and K Mukherjee. 1971. "Random Walk Hypothesis: An Empirical Study." Arthaniti 14 (1-2): 53-58.

Sasidharan, A. 2009. "Structural Changes in India's Stock Markets' Efficiency." MPRA Paper. https://mpra.ub.unimuenchen.de/19433/

Suri, Davinder. 2015."The Indian Stock Market - is it a Random Walk?" International Journal of Economic and Business Management 3(2):6-12.

Vogelsang, T J, and P Perron.1998. "Additional Tests for a Unit Root Allowing for a Break in the Trend at an Unknown Time." International Economic Review 39(4): 1073-1100. https://doi.org/10.2307/2527353

Zivolt, E, and D WK Andrews. 1992. "Further Evidence on the Great Crash, the Oil-Price Shock, and the Unit-root Hypothesis." Journal of Business and Economic Statistics 10 (3): 251-270.

Received on 13-06-2017 Accepted on 31-07-2017

Published on 24-08-2017

DOI: https://doi.org/10.6000/1929-7092.2017.06.44

(C) 2017 Chattopadhyay and Bose; Licensee Lifescience Global.

This is an open access article licensed under the terms of the Creative Commons Attribution Non-Commercial License (http://creativecommons.org/licenses/by-nc/3.0/) which permits unrestricted, non-commercial use, distribution and reproduction in any medium, provided the work is properly cited. 